\title{
Environmental impact assessment of Nigerian National Petroleum Corporation (NNPC) Awka Mega Station
}

\author{
M. A. Akintunde and Akin Olajide \\ Mechanical Engineering Department \\ Federal university of Technology, Akure, Nigeria \\ ABSTRACT
}

\begin{abstract}
In this work, the Environmental Impact Assessment (EIA) study of the NNPC mega station, Awka, was carried out. The methodology involved collection of baseline information, assessment of the project impact on the environment, preparation of environmental management plan and assessment of the effectiveness of the mitigation measures. Data for impact assessment were generated using: Overlay; Leopold matrix; Peterson matrix and Batelle environmental evaluation techniques. Overlay technique was used to collect data related to environmental factors through aerial photography, topography and land inventory mapping. Impact of interactions between the station developmental activities such as temperature, rainfall, soil, air and water qualities were determined using Leopold matrix technique. Impact of human involvement in the station project was categorized into ecological, physical, chemical, esthetical and socio-economic. From this categorization, environmental quality indices were estimated using a 0 - 1 scale function under Batelle technique. The results of the mean and standard deviation analysis of the environmental baseline data on the meteorological parameters considered, show that the percentage of the variance and/or errors from the mean is not more than $10 \%$ on the average. Hence the installation of a mega station in the study area is possible at a reduced cost and negligible effect on the environment.
\end{abstract}

\section{INTRODUCTION}

Environmental Impact Assessment (EIA) is the process by which information about the environmental effect of a project is collected, assessed and taken into account by the planning service in reaching a decision on whether the proposed development should be granted planning permission. EIA can also be defined as a systematic process to identify, predict and evaluate the environmental effect of proposed actions in order to aid decision making regarding the significant environmental consequences of projects or proposed development (1). The World Bank operational directive of 1989 states: Environmental Assessment is a flexible procedure, which can vary in breadth, depth and type of analysis, depending on the project (2). It may be carried out at one point in time, stretched over a year to account for seasonal variation, or done in discrete stages. International Association for Impact Assessment (IAIA) and institute of environmental assessment (IEA), 1999 defines EIA as the process of identifying, predicting, evaluating and mitigating the biophysical, social and other relevant effect of development proposals prior to major decision being taken and commitments made $(3,12)$. As a decision making tool, EIA compares various alternatives for a project and seek to identify the one which represents the best combination of economic and environmental costs and benefits. EIA is carried out in order to produce an environmental statement which should include: description of the project: location, design, scale, size e.t.c.; description of significant; mitigating measures and non technical summary.

A review of application of EIA in Africa shows that some forms of environmental assessment have occasionally been carried out on major development initiatives prior to its systematic institutionalization in the region. Recently, there has been a steady increase in the number of EIA to development project. The steady increase in the number of EIA application received has been attributed to the enactment of EIA legislation, the establishment of institution, increase in the level of economic activity and a general increase in awareness about EIA requirements. The sectoral distribution of EIA application depends on the dominance of the sector in the economy and its potential impacts on the environment.

EIA is one of the successful policy innovations of the $20^{\text {th }}$ century for environmental conservation. Some of what later become known as environmental assessment had started under town planning, land 
use and other policies prior to this period $(4,14)$. The first seminar on pollution of the Nigerian environment from oil industry activities was held in Port Harcourt in 1979. There has been a growing public and government concern about the pollution of the Nigerian environment. Slow poisoning of water is witnessed in this country and the destruction of vegetation and agricultural land by oil spills which occur as a result of petroleum operations. With increasing public awareness of the damage done by oil operations on the environment, government intensified measures to combat these problems.

The environmental impact assessment consists of eight steps with each step equally important in determining the overall performance of the project. These eight steps of the EIA are: Screening; Scoping; Impact analysis; Mitigation; Reporting; Review of EIA; Decision-making and Post Monitoring (4). The overview of the EIA process is represented in Fig. 1. In 1988, the NNPC was commercialized into 12 strategic business units, covering the entire spectrum of oil industry operations: exploration and production, gas development, refining, distribution, petrochemicals, engineering, and commercial investments. The proposed Mega Station at Awka is along Onitsha - Enugu expressway, Awka North Local Government Area, Anambra State, Nigeria. The area is predominantly dry land and tropical with undulating landscape. The climate is semi-humid and characterized by the typical climatic conditions of the tropics. Rainfall is heavy, temperature generally hot and relative humidity high. The map indicating the location of the project is as shown in Fig. 2.

The Federal Government of Nigeria through the NNPC is determined to ensure constant supply, availability and distribution of petroleum products throughout the federation. The Government further intends to expand the supply chain of the products and also reduce the incidence of scarcity in state capitals and major cities around the country. The necessity for the proposed project is derived from the fact that it will: enable NNPC maintain steady and efficient supply and distribution of petroleum products to the citizens of the country via the mega station facilities and provide a new retail outlet for the sale of petroleum products thereby reducing artificial scarcity. The project is further expected to significantly improve the economic base of the country and promote wider participation in the country's industrialization efforts. The main objective of this research is to assess environmental effects of NNPC mega station. The specific objectives are therefore to: collect relevant/baseline information/data for the assessment; evaluate the data for proper assessment; prepare an effective integrated environmental management system facilitates for better achievement and demonstration of sound environmental performance; propose a scheme for continued monitoring of environmental conditions during the life of the Station; and advise on mitigation of adverse potential effect of the construction, operation and decommissioning of the Station at Awka.

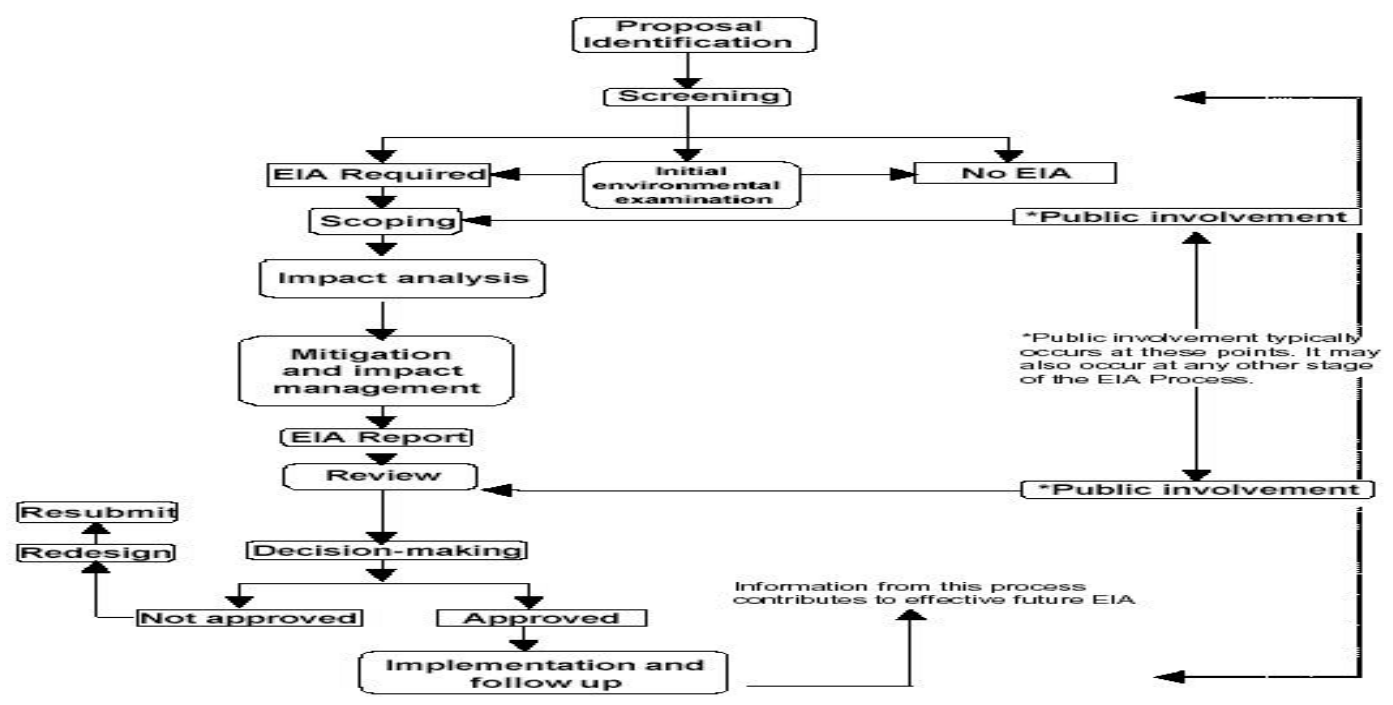

Fig 1. Generalized process flow sheet of the EIA process. 


\section{Assessment Tools}

There are several approaches and techniques developed for evaluating potential impacts of any project on the environment. Some of which were developed in the early 1970s and lean heavily upon approaches used in other spheres of environmental management $(5,13)$. The Overlays techniques; Leopold matrix (6); Battelle Environmental Evaluation System $(7,15)$ and Peterson Matrix (8) are among the most widely used methods employed for impact assessment.

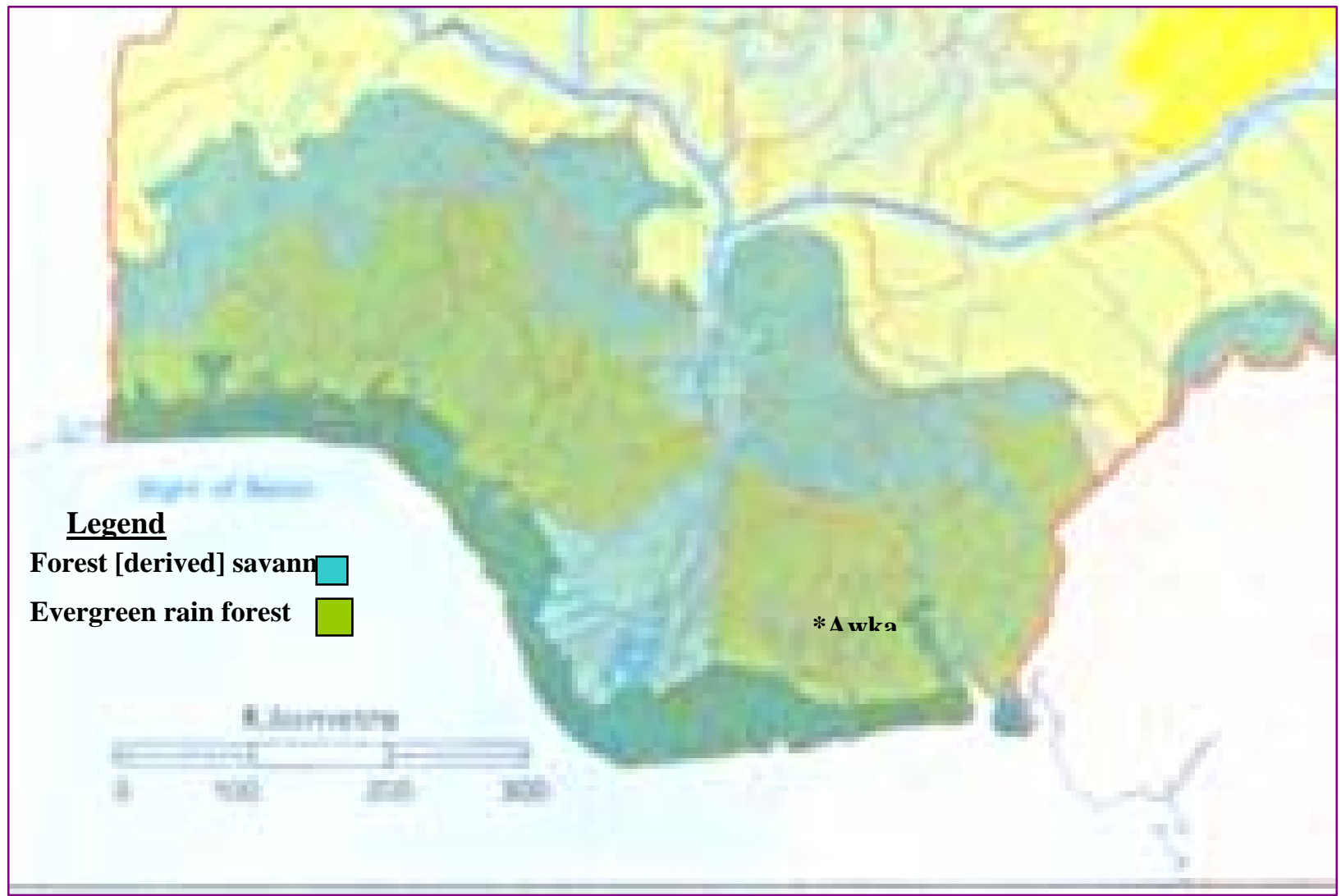

The overlay technique: The overlay technique used a series of transparencies to identify, predict, assign relative significant to, and communicates impacts in a geographical area. In this method, the study area is sub-divided into convenient geographical units, based on uniform spaced grid points, topographic features or differing land uses. Within each unit, information on environmental factors was collected, through aerial photography, topography, land inventory maps, field observations, public meetings and discussions. By a series of overlays the landuse suitability, action compatibility, and engineering feasibility are evaluated visually, in order that the best combination may be identified.

Leopold Matrix: The first to suggest the use of a matrix method for impact assessment is Leopold (6). This method is useful as it reflects the fact that impacts result from interaction of development activities and the environment. Thus, Leopold Matrix is a comprehensive checklist designed for the assessment of impacts associated with almost any type of construction project. The Leopold matrix is also used to present the results of an appraisal. Numbers representing magnitude and significance, expressed on a 10-point scale, are included in each cell indicating where a likely impact is anticipated. Positive and negative impacts are identified with ' + or '-' sign, respectively.

Battelle Environmental Evaluation System: The Battelle Environmental Evaluation system involves the separation of human concerns into four categories namely, ecology, physical/chemical, aesthetics and socio- economics. The method translates the state of individual environmental parameters into arbitrary, 
environmental quality indices all expressed in the same scale. For each component, the Battelle system develops an index of environmental quality, normalized to a scale ranging from 0 to 1 , using a value function method. Each impact indicator is given as the difference in environmental quality between the states with and those without actions. Environmental quality scores are multiplied by the appropriate weightings and added to give a total score of environmental quality for each option under consideration.

Peterson Matrix: Peterson Matrix is a modified version of Leopold matrix, adopted for the screening and scooping exercise of this project. This matrix relies directly on the multiplication properties of matrices. An ordinal scale is used to evaluate individual impacts, and separate matrix layers are produced for physical and human impacts. The matrices are also multiplied to find the effect of the casual elements on human environment while the resulting product is weighed according to the significance of the human impact.

Materials and Methodology: The EIA on the project involves capture of Baseline ecological, social and health conditions of the project environment. The Environmental Assessment Document for the project was prepared using multi-disciplinary study. The methodology adopted in conducting the EIA was summarized as: Preliminary activities; (project scoping, literature research, etc); Environmental baseline data acquisition, analysis and interpretation; Impact assessment process (identification, categorization, and evaluation of impact significance); Proffering mitigation measures (adopting industrial standard practices, project experiences, etc).

The environmental components covered include topography, climate/meteorology and air quality. Others such as soil, aquatic studies, vegetation, and land use, wildlife and biodiversity, geology/hydrogeology, waste management, socioeconomic and health survey were covered in another presentation. Sample collection was carried out as far as possible in accordance with DPR (9) Guidelines and Standards (Part (VIII) D $(2,12)$ (Sampling \& Handling of Samples)). Physicochemical parameters were determined using DREL $2000 \mathrm{HACH}$
Spectrophotometer and Orion ISE Meter Model $710 \mathrm{~A}$, duly calibrated with standards, as well as Flame Photometer. In situ measurement of wind speed, wind direction, relative humidity and temperature were carried out using Krestrel 4000 weather tracker. Complementing climate data were also obtained from the National Meteorological Agency, Oshodi, Lagos. The data collected include yearly records of rainfall, temperature, relative humidity and wind speed. The ambient suspended particulate matter (SPM) levels were sampled using the Hi-Volume sampler with its associated parts such as Vacuum pump and portable power generator. The concentrations of the air quality parameters were sampled in situ using Testo 350 - XL Avgas analyzer. Ambient temperatures were measured using the Testo $350-X \mathrm{~L}$ analyzer and a weather tracker. A SPER SCIENTIFIC Digital sound Level meter (840029) was used to measure the noise level of the location. Errors in field data include those resulting from the instrument and those introduced by the observers; these were ameliorated by proper and sustained calibration of the instrument and the use of standardized observational procedures. However, errors often arise from two-stage sampling or sub sampling, or even from the fact that the samples collected are not representative samples of the medium. There are also spatial variations of the same medium. Thus, the true mean and the estimated variance among the number of samples taken were determined, so as to establish a reasonable level of confidence in the results obtained. A good result is obtained when the variance is within $5 \%$ of the mean. More detailed methodology for the acquisition of data for each of the environmental component can be found in the work of Olajide (10).

\section{RESULTS AND DISCUSSIONS}

The proposed Mega Station, Awka, is about $50 \mathrm{~km}$ along Onitsha - Enugu expressway, Awka South Local Government Area, Anambra State, Nigeria. The area is predominantly dry land and tropical with undulating landscape. The climate is semi-humid and characterized by the typical climatic conditions of the tropics. Rainfall is heavy; temperature and relative humidity are generally high. The map showing the exact location of the proposed project site is as shown in Fig. 2. 
Am. J. Sci. Ind. Res., 2011, 2(4): 511-520

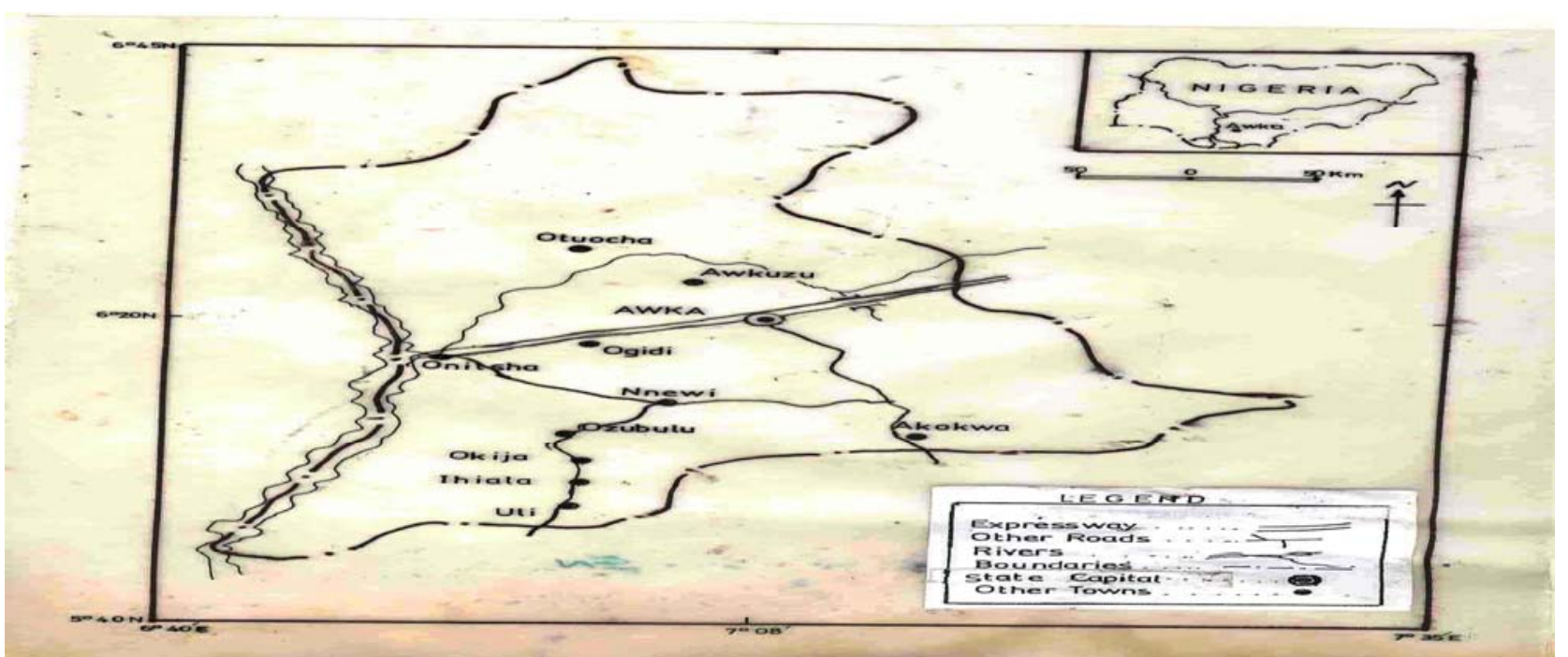

Fig. 2 Map of the Study Area

Table 1 shows the results of the meteorological Data measured during the field sampling, while Tables 2 to 6 present rainfall, wind, air-quality and noise levels respectively. These records are similar to those obtained from the National Meteorological Agency for about 10 year period $(1995-2004)$ in the study area.

Table 1: Average Meteorological Data of the Study Area

\begin{tabular}{|c|c|c|c|c|c|c|c|c|c|c|c|c|}
\hline \multirow{2}{*}{$\begin{array}{l}\text { S/N } \\
1\end{array}$} & \multirow{2}{*}{$\begin{array}{l}\text { Locations } \\
\text { Point } 1\end{array}$} & \multirow{2}{*}{$\begin{array}{l}\text { CORDINATES } \\
06^{\circ} 13^{\prime \prime} 01^{\prime} \mathrm{N} \\
07^{\circ} 02^{\prime \prime} 57 \mathrm{E}^{\prime}\end{array}$} & \multicolumn{2}{|c|}{$\begin{array}{l}\text { Temp }\left({ }^{\circ} \mathrm{C}\right) \\
\text { DRY WET }\end{array}$} & \multicolumn{2}{|c|}{$\begin{array}{l}\text { Wind Direction } \\
\text { DRY WET }\end{array}$} & \multicolumn{2}{|c|}{$\begin{array}{l}\begin{array}{l}\text { Wind } \\
(\mathrm{m} / \mathrm{s})\end{array} \\
\text { DRY }\end{array}$} & \multicolumn{2}{|c|}{$\begin{array}{l}\text { Relative } \\
\text { Humidity (\%) }\end{array}$} & \multicolumn{2}{|c|}{$\begin{array}{l}\text { Atmospheric Pressure } \\
(\mathrm{mm} / \mathrm{Hg})\end{array}$} \\
\hline & & & 40.0 & 31.0 & SE & SE & 1.8 & 1.2 & 34.0 & 66 & 746.3 & 749.3 \\
\hline 2 & Point 2 & $\begin{array}{l}06^{\circ} 13^{\prime \prime} 15^{\prime} \mathrm{N} \\
07^{\circ} 02^{\prime \prime} 55^{\prime} \mathrm{E}\end{array}$ & 42.0 & 31 & SE & SE & 1.6 & 0.9 & 32.0 & 65 & 745.5 & 749.3 \\
\hline 3 & Point 3 & $\begin{array}{l}06^{\circ} 13^{\prime \prime} 04^{\prime} \mathrm{N} \\
07^{\circ} 02^{\prime \prime} 58^{\prime} \mathrm{E}\end{array}$ & 36.0 & 32 & SE & SE & 1.8 & 0.8 & 41.0 & 66 & 745.5 & 749.3 \\
\hline 4 & Point 4 & $\begin{array}{l}06^{\circ} 13^{\prime \prime} 03{ }^{\prime} \mathrm{N} \\
07^{\circ} 03^{\prime \prime} 01^{\prime} \mathrm{E}\end{array}$ & 36.0 & 36 & SE & SW & 1.4 & 1.1 & 44.0 & 50 & 745.5 & 749.3 \\
\hline 5 & Point 5 & $\begin{array}{l}06^{\circ} 13^{\prime \prime} 07^{\prime} \mathrm{N} \\
07^{\circ} 03^{\prime \prime} \quad 02 \text { 'E }\end{array}$ & 37.0 & 36 & SE & SE & 1.2 & 0.9 & 47.0 & 51 & 745.5 & 749.3 \\
\hline 7 & Point 7 & $\begin{array}{l}06^{\circ} 13^{\prime \prime} 00^{\prime N} \\
07^{\circ} 02^{\prime \prime} 58^{\prime} \mathrm{E}\end{array}$ & 41.0 & 38 & SE & SE & 1.9 & 1.0 & 33.0 & 43 & 744.7 & 748.5 \\
\hline & $\begin{array}{l}\text { Average } \\
\text { Values }\end{array}$ & & 38.7 & 34.6 & SE & SE & 1.8 & 0.96 & 38.0 & 55 & 745.5 & 749.1 \\
\hline
\end{tabular}




\begin{tabular}{|l|l|l|l|l|l|l|l|l|l|l|l|l|}
\hline & & \multicolumn{7}{|l|}{ RAINFALL (mm) } & & & & \\
\hline YEAR & JAN & FEB & MAR & APR & MAY & JUN & JUL & AUG & SEP & OCT & NOV & DEC \\
\hline 1995 & 59.6 & 12.5 & 72.2 & 115.9 & 361.5 & 339.2 & 484 & 381.6 & 460.9 & 292.4 & 26.7 & 15.8 \\
\hline 1996 & 21.1 & 74.6 & 68.7 & 238.4 & 252.7 & 395.3 & 350 & 502 & 573.2 & 228 & 1.5 & Trace \\
\hline 1997 & 31.7 & 0.0 & 215.1 & 309.8 & 542.7 & 504.8 & 311.9 & 304.3 & 242.5 & 262.5 & 137.4 & 28.7 \\
\hline 1998 & 14.6 & 0.0 & 48.7 & 130.5 & 253.7 & 289.4 & 288.9 & 168.5 & 254.2 & 179.2 & 12.4 & 0.0 \\
\hline 1999 & 49.1 & 73.9 & 118.7 & 161.5 & 256.7 & 218.3 & 270.5 & 302.7 & 609 & 354.5 & 100.5 & 0.0 \\
\hline 2000 & 39.1 & 0.0 & 53.2 & 354.2 & 47.3 & 391.8 & 382.7 & 356.4 & 344 & 246.5 & 116.5 & 5.5 \\
\hline 2001 & 5.5 & 62 & 206.4 & 172.2 & 140.8 & 385.4 & 301.7 & 348.7 & 430.8 & 213.4 & 22.6 & 14.8 \\
\hline 2002 & 27.9 & 90.4 & 241.7 & 265.6 & 198.3 & 391.5 & 131.5 & 293.5 & 372.4 & 40.9 & 0.0 & 0.0 \\
\hline 2003 & 92.6 & 136.9 & 73.3 & 278.1 & 277.4 & 439.5 & 379.2 & 476.4 & 123.8 & 50.6 & 28.1 & 6.0 \\
\hline 2004 & 73.5 & 32.4 & 173.3 & 163.1 & 225.2 & 240.4 & 185.4 & 309.1 & 322.9 & 37.0 & 0.0 & 1.3 \\
\hline 2005 & 35.5 & 58.4 & 102.6 & 194.3 & 469.8 & 367 & 260 & 302.4 & 232.9 & 199.8 & 13.9 & Trace \\
\hline
\end{tabular}

Table 2: Average Rainfall Measurements for 10-Year Period in the Study Area

Table 3: Mean Wind Speed Records in the Study Area

\begin{tabular}{|l|l|l|l|l|l|l|l|l|l|l|l|l|}
\hline & & \multicolumn{9}{|l|}{ WIND SPEED (m/s) } \\
\hline YEAR & JAN & FEB & MAR & APR & MAY & JUN & JUL & AUG & SEP & OCT & NOV & DEC \\
\hline 1995 & 2.9 & 3.6 & 3.4 & 3.5 & 2.8 & 3.3 & 2.5 & 2.5 & 2.9 & 2.6 & 2.3 & 2.6 \\
\hline 1996 & 3.1 & 2.7 & 3.0 & 2.8 & 2.9 & 2.8 & 2.5 & 2.3 & 2.7 & 2.5 & 2.6 & 2.2 \\
\hline 1997 & 2.7 & 2.7 & 3.2 & 3.2 & 3.0 & 2.9 & 2.4 & 2.1 & 2.9 & 2.6 & 2.7 & 3.2 \\
\hline 1998 & 4.3 & 4.1 & 4.9 & 4.6 & 4.2 & 4.0 & 2.9 & 5.3 & 4.9 & 2.7 & 2.6 & 2.7 \\
\hline 1999 & 2.8 & 3.3 & 3.5 & 4.5 & 3.9 & 3.4 & 3.0 & 4.2 & 4.0 & 4.0 & 2.3 & 2.9 \\
\hline 2000 & 3.6 & 4.0 & 3.2 & 3.7 & 3.5 & 3.7 & 3.2 & 4.2 & 4.0 & 4.0 & 2.5 & 2.4 \\
\hline 2001 & 8.1 & 4.1 & 3.3 & 3.8 & 3.4 & 3.3 & 3.2 & 2.9 & 2.5 & 2.2 & 2.8 & 4.3 \\
\hline 2002 & 3.1 & 4.1 & 4.1 & 3.8 & 3.5 & 3.7 & 3.4 & 3.0 & 2.8 & 2.6 & 3.1 & 4.6 \\
\hline 2003 & 3.6 & 3.3 & 3.8 & 3.6 & 3.8 & 3.8 & 3.8 & 3.7 & 3.4 & 3.3 & 2.8 & 3.2 \\
\hline 2004 & 3.7 & 3.5 & 2.4 & 2.9 & 2.7 & 3.5 & 3.5 & 3.7 & 2.9 & 2.3 & 2.0 & 3.1 \\
\hline
\end{tabular}

Source: National Meteorological Agency, Lagos.

Table 4 Prevailing Wind Directions around the Study Area

\begin{tabular}{|c|c|c|c|c|c|c|c|c|c|c|c|c|}
\hline \multirow[b]{2}{*}{ YEAR } & \multirow[b]{2}{*}{ JAN } & \multirow[b]{2}{*}{ FEB } & \multicolumn{5}{|c|}{ Wind Direction } & \multirow[b]{2}{*}{ AUG } & \multirow[b]{2}{*}{ SEP } & \multirow[b]{2}{*}{ OCT } & \multirow[b]{2}{*}{ NOV } & \multirow[b]{2}{*}{ DEC } \\
\hline & & & MAR & APR & MAY & JUN & JUL & & & & & \\
\hline 1995 & W & W & SW & S & $S$ & W & SW & W & W & W & W & $\mathrm{NE}$ \\
\hline 1996 & W & $\mathrm{NE}$ & $\mathrm{W}$ & SW & SW & $\mathrm{S}$ & SW & SW & SW & SW & SW & $E$ \\
\hline 1997 & NE & $\mathrm{NE}$ & W & SW & SW & SW & SW & SW & SW & SW & SW & W \\
\hline 1998 & NE & SW & SW & SW & $S$ & SW & W & SW & SW & SW & W & W \\
\hline 1999 & W & SW & $S$ & $\mathrm{~S}$ & $\mathrm{~S}$ & $S$ & $S$ & $\mathrm{~S}$ & SW & $S$ & SW & W \\
\hline 2000 & NE & SW & SW & SW & SW & SW & SW & SW & SW & SW & SW & NE \\
\hline 2001 & SW & NE & SW & SW & SW & SW & SW & SW & SW & SW & SW & NE \\
\hline 2002 & NE & $\mathrm{NE}$ & SW & SW & SW & SW & SW & SW & SW & SW & SW & $E$ \\
\hline 2003 & NE & $\mathrm{NE}$ & SW & SW & W & SW & W & W & SW & SW & SW & $E$ \\
\hline 2004 & W & W & $S$ & $S$ & $S$ & $S$ & S & W & $\mathrm{S}$ & $S$ & $S$ & W \\
\hline
\end{tabular}

Source: National Meteorological Agency, Lagos. 
Generally, the study area has a humid, semi-hot equatorial climate with adequate sunshine distribution. The recorded average temperature is between $20.1-36{ }^{\circ} \mathrm{C}$. However, average ambient air temperature recorded over the sampling period ranged from 36.0 to $42.0^{\circ} \mathrm{C}$ with an average of $38.7^{\circ} \mathrm{C}$ in the dry season and 31 to $38{ }^{\circ} \mathrm{C}$ with an average $34.5{ }^{\circ} \mathrm{C}$ in the wet season. Such temperature differences are responsible for the generation of turbulence necessary for transport of pollutants, in combination with pressure difference, which directly affect the mean wind vector.

The daily average relative humidity was generally high and ranges between $60-90 \%$. The relative humidity during field measurements ranged from 32 to $47 \%$ with an average of $38.0 \%$ in the dry season and 43 to $66 \%$ in the wet season with a mean value of $55 \%$. The atmospheric pressure ranged from $744.7-746.3 \mathrm{~mm} / \mathrm{Hg}$ with a mean of $745.5 \mathrm{~mm} / \mathrm{Hg}$ in the dry season and 748.5 to $749.3 \mathrm{~mm} / \mathrm{Hg}$ with an average of $749.5 \mathrm{~mm} / \mathrm{Hg}$ in the wet season.

Table 6 compared the noise levels obtained during the dry and wet seasons sampling with FMEnv and DPR statutory limits. The noise levels measured ranged from $48.2 \mathrm{~dB}(\mathrm{~A})$ to $67.6 \mathrm{~dB}(\mathrm{~A})$ with an average of $54.6 \mathrm{~dB}(A)$ during dry season and from $60.1 \mathrm{~dB}(\mathrm{~A})$ to $79.8 \mathrm{~dB}(\mathrm{~A})$ with mean value of 65.9 $\mathrm{dB}(A)$ in the wet season. The recorded noise data are within tolerable limits of $80-90 \mathrm{~dB}(\mathrm{~A})$ specified by FMENV and DPR guidelines.

Table 5 Air quality Measurements in Awka Mega station.

\begin{tabular}{|c|c|c|c|c|c|c|c|c|c|c|c|c|c|c|c|}
\hline \multirow[t]{2}{*}{ LOCATIONS } & \multirow[t]{2}{*}{ CORDINATES } & $\begin{array}{l}\mathrm{SO}_{2} \\
\text { (ppr } \\
\text { DRY }\end{array}$ & ) & CO & opm) & $\mathrm{H}_{2} \mathrm{~S}$ & (ppm) & $\begin{array}{l}\text { Cxh } \\
\text { (pp }\end{array}$ & & NOr & pm) & NO & pm) & \multicolumn{2}{|c|}{$\operatorname{TSP}\left(\mu \mathrm{g} / \mathrm{m}^{3}\right)$} \\
\hline & & & & & & & & DRY & WET & & & & & & \\
\hline POINT 1 & $\begin{array}{l}06^{\circ} 13^{\prime \prime} 01^{\prime} \mathrm{N} \\
07^{\circ} 02, " 57 \mathrm{E}^{\prime}\end{array}$ & ND & ND & ND & ND & ND & ND & ND & ND & ND & ND & ND & ND & $<0.01$ & $<0.01$ \\
\hline POINT 2 & $\begin{array}{l}06^{\circ} 13^{\prime \prime} 15^{\prime} \mathrm{N} \\
07^{\circ} 02^{\prime \prime} 55^{\prime} \mathrm{E}\end{array}$ & ND & ND & ND & ND & ND & ND & ND & ND & ND & ND & ND & ND & $<0.01$ & $<0.01$ \\
\hline POINT 3 & $\begin{array}{l}06^{\circ} 13^{\prime \prime} 04^{\prime} \mathrm{N} \\
07^{\circ} 02^{\prime \prime} 58^{\prime} \mathrm{E}\end{array}$ & ND & ND & ND & ND & ND & ND & $\mathrm{ND}$ & ND & ND & ND & $\mathrm{ND}$ & ND & $<0.01$ & $<0.01$ \\
\hline POINT 4 & $\begin{array}{l}06^{\circ} 13^{\prime \prime} 03^{\prime} \mathrm{N} \\
07^{\circ} 03^{\prime \prime} \quad 01^{\prime} \mathrm{E}\end{array}$ & ND & ND & ND & ND & ND & ND & ND & ND & ND & ND & ND & ND & $<0.01$ & $<0.01$ \\
\hline POINT 5 & $\begin{array}{l}06^{\circ} 13^{\prime \prime} \quad 07^{\prime} \mathrm{N} \\
07^{\circ} 03^{\prime \prime} \quad 02^{\prime} \mathrm{E}\end{array}$ & ND & ND & ND & ND & ND & ND & ND & ND & ND & ND & ND & ND & $<0.01$ & $<0.01$ \\
\hline POINT 6 & $\begin{array}{l}06^{\circ} 12^{\prime \prime} 59^{\prime} \mathrm{N} \\
07^{\circ} 02^{\prime \prime} \quad 59^{\prime} \mathrm{E}\end{array}$ & ND & ND & ND & ND & ND & ND & ND & ND & ND & ND & ND & ND & $<0.01$ & $<0.01$ \\
\hline POINT 7 & $\begin{array}{l}06^{\circ} 13^{\prime \prime} 00{ }^{\prime} \mathrm{N} \\
07^{\circ} 02^{\prime \prime} 58^{\prime} \mathrm{E}\end{array}$ & ND & ND & ND & ND & ND & ND & ND & ND & ND & ND & ND & ND & $<0.01$ & $<0.01$ \\
\hline $\begin{array}{l}\text { Average } \\
\text { Values }\end{array}$ & & ND & ND & ND & ND & ND & ND & ND & ND & ND & ND & ND & ND & $<0.01$ & $<0.01$ \\
\hline
\end{tabular}

Key: ND = Not Detected; TSP $=$ Total Suspended Particles 
Am. J. Sci. Ind. Res., 2011, 2(4): 511-520

Table 6: Noise levels of the Study Area.

\begin{tabular}{|c|c|c|c|c|}
\hline \multirow[t]{2}{*}{$S / N$} & \multirow[t]{2}{*}{ LOCATIONS } & \multirow[t]{2}{*}{ CORDINATES } & \multicolumn{2}{|c|}{ Noise Level (dBA) } \\
\hline & & & \multicolumn{2}{|l|}{$\begin{array}{l}\text { DRY } \\
\text { WET }\end{array}$} \\
\hline 1 & Point 1 & $\begin{array}{l}06^{\circ} 13^{\prime \prime} 01^{\prime} \mathrm{N} \\
07^{\circ} 02^{\prime \prime} 57 \mathrm{E}^{\prime}\end{array}$ & 48.2 & 79.8 \\
\hline 2 & Point 2 & $\begin{array}{l}06^{\circ} 13^{\prime \prime} 15^{\prime} \mathrm{N} \\
07^{\circ} 02^{\prime \prime} 55^{\prime} \mathrm{E}\end{array}$ & 48.8 & 68.4 \\
\hline 3 & Point 3 & $\begin{array}{l}06^{\circ} 13^{\prime \prime} 04^{\prime} \mathrm{N} \\
07^{\circ} 02^{\prime \prime} 58^{\prime} \mathrm{E}\end{array}$ & 50.4 & 66.5 \\
\hline 4 & Point 4 & $\begin{array}{l}06^{\circ} 13^{\prime \prime} 03^{\prime} \mathrm{N} \\
07^{\circ} 03^{\prime \prime} \text { 01'E }\end{array}$ & 67.6 & 66.2 \\
\hline 5 & Point 5 & $\begin{array}{l}06^{\circ} 13^{\prime \prime} 07^{\prime} \mathrm{N} \\
07^{\circ} 03^{\prime \prime} \quad 02^{\prime} \mathrm{E}\end{array}$ & 54.7 & 60.1 \\
\hline 6 & Point 6 & $\begin{array}{l}06^{\circ} 12^{\prime \prime} 59^{\prime} \mathrm{N} \\
07^{\circ} 02^{\prime \prime} 59^{\prime} \mathrm{E}\end{array}$ & 53.0 & 72.9 \\
\hline \multirow[t]{3}{*}{7} & Point 7 & $\begin{array}{l}06^{\circ} 13^{\prime \prime} 00{ }^{\prime} \mathrm{N} \\
07^{\circ} 02^{\prime \prime} 58^{\prime} \mathrm{E}\end{array}$ & 59.6 & 77.6 \\
\hline & $\begin{array}{l}\text { Average } \\
\text { Values }\end{array}$ & & 54.6 & 70.2 \\
\hline & $\begin{array}{l}\text { FMEnv and } \\
\text { DPR Limit }\end{array}$ & & $80-90$ & $80-90$ \\
\hline
\end{tabular}

The screening of the project activities indicated that clearing of vegetation, dredging, transportation of materials to site during construction phase, presence of infrastructure during operational phase pose a threat to the biotic and abiotic components. Most of the adverse effect will come from construction phase involving the installation of mega station and dredging. These impacts are expected to be shortterm and shall cease with the completion of the construction phase. Impacts from operational phase are expected to be long term. The social components are expected to have beneficial impacts like the recruitment of labour force.

The impact indicators are defined and adopted so as to identify potential environmental impacts. Impact indicators are the easily observable environmental components, which readily indicate changes. The impact indicators used for this study are presented in Table 7.

Table 7: Environmental Components and Potential Impact Indicators

\begin{tabular}{|l|l|}
\hline $\begin{array}{l}\text { Environmental } \\
\text { Components }\end{array}$ & \multicolumn{1}{c|}{ Impact Indicator } \\
\hline Climate & Temperature, Rainfall, Relative Humidity, wind \\
\hline Air Quality & Particulate, $\mathrm{NO}_{x}, \mathrm{SOx} \mathrm{CO}_{2}, \mathrm{CO}, \mathrm{VOC}$. \\
\hline
\end{tabular}

The scoping of potential impacts involves identifications of interactions between project activities and environmental impact indicators. This stage of the impact assessment process simply qualifies impacts as beneficial or as adverse. Ranking of the potential impacts at this stage is done on a scale of 1 to 5 and the interpretations as follows: 1 = Very low impact; 2 = Low impact; 3 = Moderate impact; $4=$ High impact; $5=$ Very high impact; + = Positive impact and - = Negative impact.
The ranking, relative to recovery period was as follow: Transient - A few hours to some days; Short term - $\leq 6$ months; Medium - 6 - 12 months Long term - > 12 Months; Very long/permanent $-\leq 5$ years

The proposed Mega Station has been evaluated and some of the identified activities, which could adversely impact the environment in the area, are transportation of equipment and materials, 
Am. J. Sci. Ind. Res., 2011, 2(4): 511-520

underground tank burying (trenching, backfilling, etc) operations, maintenance and abandonment. The evaluation of the impact of these activities on various environmental components is presented in Table 8.

Table 8: Aggregated Potential Environmental Impact Evaluated for the Mega Station.

\begin{tabular}{|c|c|c|c|c|c|c|c|c|}
\hline $\begin{array}{l}\text { Project Activities } \\
\text { Environmental } \\
\text { Component (x) }\end{array}$ & 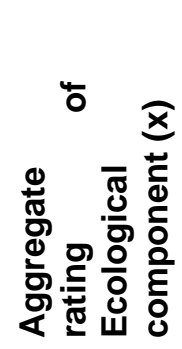 & $\begin{array}{l}\frac{5}{0} \\
\frac{0}{\pi} \\
\frac{\pi}{0} \\
\frac{0}{0} \\
\frac{0}{2} \\
\frac{0}{0} \\
\frac{0}{0}\end{array}$ & 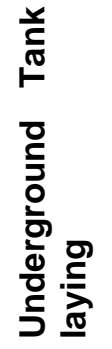 & 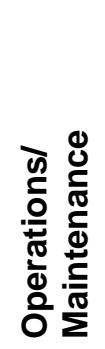 & $\begin{array}{l}\frac{\pi}{0} \\
\frac{0}{0} \\
\frac{0}{\pi} \\
\frac{\pi}{\pi} \\
\frac{0}{\pi} \\
\frac{\pi}{2} \\
\frac{\pi}{\pi} \\
\frac{\pi}{\pi}\end{array}$ & 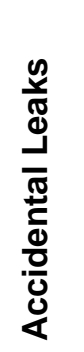 & 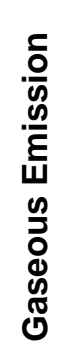 & 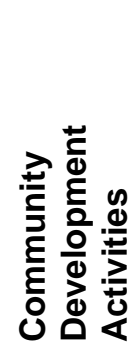 \\
\hline $\begin{array}{l}\text { CLIMATE/METEOROLOGY } \\
\text { Temperature } \\
\text { Rainfall } \\
\text { Humidity }\end{array}$ & $\begin{array}{l}1 \\
1 \\
1\end{array}$ & N.A. & N.A & N.A & N.A & N.A & N.A & N.A \\
\hline $\begin{array}{l}\text { AIR QUALITY } \\
\text { S. P. M. } \\
\text { CO }_{x} \\
\text { VOC }\end{array}$ & $\begin{array}{l}2 \\
2 \\
2\end{array}$ & $\begin{array}{l}-1 \\
-1 \\
-1\end{array}$ & & $\begin{array}{l}-1 \\
-1 \\
-1\end{array}$ & & $\begin{array}{l}-2 \\
-2 \\
-2\end{array}$ & $\begin{array}{l}-1 \\
-1 \\
-1\end{array}$ & \\
\hline $\begin{array}{l}\text { SURFACE WATER } \\
\text { PHYSICO-CHEMISTRY } \\
\text { Turbidity and solids } \\
\text { Oil and Grease } \\
\text { Toxicity }\end{array}$ & $\begin{array}{l}4 \\
4 \\
4\end{array}$ & -3 & $\begin{array}{l}-3 \\
-2\end{array}$ & $\begin{array}{l}-2 \\
-2\end{array}$ & -1 & $\begin{array}{l}-1 \\
-2\end{array}$ & N.A & N.A \\
\hline $\begin{array}{l}\text { SOILS/LANDUSE } \\
\text { Soil fertility/Productivity } \\
\text { Soil Erosion } \\
\text { Land take }\end{array}$ & $\begin{array}{l}2 \\
3 \\
3\end{array}$ & $\begin{array}{l}-1 \\
-3 \\
\text { N.A }\end{array}$ & $\begin{array}{l}-3 \\
-3\end{array}$ & $\begin{array}{l}-1 \\
-1 \\
-1\end{array}$ & $\begin{array}{l}\text { N.A } \\
\text { N.A } \\
\text { N.A }\end{array}$ & $\begin{array}{l}-3 \\
\text { N.A } \\
\text { N.A }\end{array}$ & $\begin{array}{l}\text { N.A } \\
\text { N.A } \\
\text { N.A }\end{array}$ & $\begin{array}{l}\text { N.A } \\
\text { N.A } \\
\text { N.A }\end{array}$ \\
\hline
\end{tabular}

Although some of the activities shall adversely affect the environment, the impact shall be insignificant since these activities shall be carried out only at the construction phase of the project that will be for a very short duration. Consequently, these adverse impacts will be localized and transient. In addition, mitigation measures have been proffered, to eliminate or reduce these impacts to manageable levels. However, the long-term impacts from the project shall be beneficial. These include increase business activities, uninterrupted availability and distribution of petroleum products, employment opportunities for skilled and unskilled labour and community development activities.

Impact on Ecological (Natural) Environmental and Resources Utilization: The use of heavy equipment for construction and excavation activities could generate nuisance in form of dust, noise emission and vibrations. The noise from these activities might impair hearing. Also emissions of (SPM, $\mathrm{CO}_{x}, \mathrm{SO}_{\mathrm{x}}$, and $\mathrm{NO}_{\mathrm{x}}$ ) from construction/excavation equipment could impair air quality (11). The noise level would be highest in areas where heavy machinery is being operated, but it would fade off with increasing distance from the construction site. The current 
ambient levels of noise and sounds in the project area are low. Significant increase is envisaged during mobilisation of equipment and personnel and during construction and welding. High levels of noise could lead to noise induced hearing loss and may also lead to psychosocial effects.

Conclusions and Recommendations: A multidisciplinary approach was adopted in the assessment of the environmental status and sensitivities of the various ecological components of the NNPC Mega Station, Awka Project area using extensive literature search, field sampling and measurement/testing and laboratory analyses. The Mega Station, Awka Project will have significant beneficial impacts on the national economy and the socio-economic life of the host communities. These would result from the sale of petroleum products, employment of indigenous labour/contractors, and the socio-economic gains to the host communities.

The Environmental Impact Assessment (EIA) report shows that the NNPC Mega Station, Awka Project will have adverse impact on land-use, air, socioeconomic, health and the environment on short-term basis. The EIA report also indicates that these adverse impacts can be reduced to as low as reasonably practicable (ALARP) levels by the application of proven best available technology (BAT) in the oil and gas industry that meet national and international standards and codes of practice. Moreover, an Environmental Management Plan (EMP) has been developed for the project and would ensure that procedures for managing the adverse potential impacts of the proposed project on the environment are developed, established and maintained throughout the life cycle of the project. From the foregoing, therefore, NNPC Mega Station, Awka Project is considered environmentally friendly.

\section{REFERENCES}

1 Abebe A. and Smith D. (2005): Pile Foundation Design: A Student Guide. School of Built Environment, Napier University Edinburgh.

2 FEPA - Federal Environmental Protection Agency (1991). National Guidelines and Standards for Industrial Effluents, Gaseous Emissions and Hazards Waste Management in Nigeria.

3 Carter, G.R. and A. Chadwick, (1997): Introduction to Environmental Impact Assessment; principles and procedures, process, practice and prospects .University College London Press, London.
4 Goodland R;Mercier J.R (1996): Environmental Assessment (EA) in Africa ; A World Bank commitment, proceeding of the Durban World Bank Workshop ,June 25,1995.

5 Gilpin A.(1995):Environmental Impact Assessment ( EIA):Cutting -edge for the twenty first centry.Cambridge university Press, Cambridge.

6 Leoplod, K. S.; Smith, R. T. and K. Akinson (1975). Techniques in Pedology A. Handbook for Environmental and Resources Studies. Elek. Science. London pp. 24-36.

7 Dee, A. C.; Walkey, A. and I. A. Black (1973). Determination of Organic Carbon in Soils Sc. pp.37:29-38.

8 Peterson, B. S. and A.E.Lugo (1974). A comparison of Structural and Functional characteristics of saltwater and fresh water forested wetlands. In: Wet lands: Ecology and Management. B. Gopal et al., (Eds.)

Part 1 (C.A. Black et al. Ed). American Soc. Of Agronomy Inc: Wisconsin. U.S.A. pp.545-567.

9 DPR Guidelines and Standards (1991). Environmental Guideline and Standards for the Petroleum Industry in Nigeria.

10 Olajide, A. (2010), Environmetal Impact Assessment of Nigeria National Petroleum Corporation (NNPC): Awka Mega Station AS A Case Study. M.Eng. Thesis at the Department of Mechanical Engineering. The Federal University of Technology, Akure, Nigeria.

11 Amadi, S.A. (2004). Analysis of Corrosion Induced Failure of Oil Pipeline in the Marine Environment and Possible Control Measures. Vol.1, No.1 JAEET. pp1724.

12 Ewards, A.W.A. 1990. Wetlands in southern Nigeria. In: Nigerian Wetlands. Selected papers from the Man and the Biosphere National Committee Workshop. Eds. Akpata, T.V.I. and Okali, D.U.U.

13 Odu, C. T. I., O. F. Esuruoso, C. Nwobishi and J. A. Ogunwale (1985). Environmental Study of the Nigeria Agip Oil Company, Operational areas. Soils and Freshwater Vegetation. Milan Italy.

14 Song, H.G. and Bartha (1990): Effect of jet fuel spills on the Microbial Community of Soil. Applied Environmental Microbiology. 36:648.

15 Thomas, G.W. (1982). Exchangeable Cations. In: A.L. Page, R.H. Miler and D.R. Keeney (eds.) Methods of Soil Analysis. Argon. Series 9. ASA and SSSA. Maidson, Wisconsin. pp, 159-161. 